\title{
Organic carbon density and storage of the major black soil regions in Northeast China
}

\author{
H. Li ${ }^{1}$, J.B. Pei1 ${ }^{2}$, J.K. Wang ${ }^{1 *}$, S.Y. Li ${ }^{1}$, G.W. Gao ${ }^{3}$ \\ ${ }^{1}$ College of Land and Environment, Shenyang Agricultural University, Ministry of Agriculture Key Laboratory of Northeast \\ Cultivated Land Conservation, Shenyang 110866, P. R. China. ${ }^{2}$ Wetland Biogeochemistry Laboratory, Soil and Water Science \\ Department, University of Florida, Gainesville, FL 32611, USA. ${ }^{3}$ Shandong Tiancheng Land Consolidation Co., LTD, Jinan \\ 250014, P. R. China. "Corresponding author: j-kwang@163.com
}

\begin{abstract}
Black soils in the Northeast Plain of China are characterized by high organic carbon (C) density and storage, which can influence $\mathrm{C}$ sequestration in local cropland ecosystems. Using GIS, this study analyzed the temporal and spatial distribution and variation of cropland organic $\mathrm{C}$ density and storage in the arable layer $(0-20 \mathrm{~cm})$ of the major black soil regions in China's Northeast Plain (specifically across the study region of Hailun, Shuangcheng and Gongzhuling counties) over the past 30 years. The results indicate an overall downward trend in soil organic $\mathrm{C}$ (SOC) density (SOCd, mean decrease of $0.64 \mathrm{~kg} \mathrm{~m}^{-2}$ ) and storage (SOCs, decrease of $4.65 \mathrm{Tg}$ )*1 for the major black soil regions tested during the study period. The mean decrease in SOCd for Hailun, Shuangcheng and Gongzhuling counties was $0.68 \mathrm{~kg} \mathrm{~m}^{-2}, 0.18 \mathrm{~kg} \mathrm{~m}^{-2}$ and $1.05 \mathrm{~kg} \mathrm{~m}^{-2}$, respectively, with total SOC decreases of 2.30 $\mathrm{Tg}, 0.49 \mathrm{Tg}$ and $1.86 \mathrm{Tg}$, respectively. SOCd decreased to a greater extent during the first twenty years in Hailun and Shuangcheng relative to Gongzhuling. Moreover, SOCd tended to stabilize and then slightly increase during the last ten years. There was a downward trend in SOCd and SOCs over the past 30 years for almost all soil types, but the most serious decline in SOCs was observed in black soils, which account for $57.92 \%$ of the cropland soil area in all study regions and which lost up to $2.91 \mathrm{Tg}$ of SOC. Therefore, the major black soil region in Northeast China was presenting a $\mathrm{C}$ resource trend over the past $20-30$ years.
\end{abstract}

Keywords: Black soil, organic carbon density and storage, arable layer, Northeast China

$* 11 \mathrm{Tg}=1012 \mathrm{~g}$. 


\section{Introduction}

Soil organic carbon (C) is a very important soil component in cropland ecosystems; it is essential for protecting and maintaining soil structure and quality (Yu et al., 2009; Han et al., 2010). The soil organic carbon pool $\left(\mathrm{SOC}_{\mathrm{P}}\right)$ is an important part of the global carbon pool and plays an essential role in global climate change and ecosystem stability (Xie et al., 2004; Franzluebbers, 2010). Since the 1980s, many researchers and scientists, such as Bohn (1982), Bernoux et al. (2002), Thorburn et al. (2012) and Kumar et al. (2013), have estimated the SOCP in different countries using investigation data from each. Lal (2004) estimated that globally soil C pool (2500 $\mathrm{Pg}, 1 \mathrm{Pg}=10^{15} \mathrm{~g}$ ) includes about $60 \%$ of soil organic C and $40 \%$ of inorganic C. Meanwhile, the same types of studies were conducted in China. Sun et al. (2005) estimated SOCd and SOCs based on the 1:1 millionscale soil database of China, while Pan (1999), Huang et al. (2006) and Liu (2011) also estimated SOCd and SOCs using the one-meter profile data but in different local soils. Many studies have found that SOC is highly sensitive to human activities (Piao et al., 2009; Qin et al., 2013), meanwhile, SOCd and SOCs in the arable layer $(0-20 \mathrm{~cm})$ are higher than in the other soil profile layers but also more variable and sensitive than the deeper intervals of the soil profile (Wu, 2007; Liu, 2011; Edmondson et al., 2012).

The black soil region in NE China (equivalent to the Mollisol soil type in the USDA soil classification system) is one of the three most important black soil regions in the world (Fan et al., 2005). This rigon is characterized by high SOCd and SOCs, and has a very important effect on $\mathrm{C}$ sequestration and local food security in Chinese cropland ecosystems (Xi et al., 2011). Sun W.X. et al. (2004) estimated SOCd (a mean of $16.13 \mathrm{~kg} \mathrm{~m}^{-2}$ ) based on the 1:1 million-scale soil database of China and the properties of 736 soil profiles noted in Soil Species of China, Soil Species of Heilongjiang Province and Soil Species of Jilin Province during the period of the second national soil survey in China (1979-1985). Wu et al. (2007) calculated the SOCd (a mean of $6.27 \mathrm{~kg} \mathrm{~m}^{-2}$ ) and SOCs (292 Tg) in seven cities and counties of NE China based on the 1:200,000-scale soil database, with 503 samples measured from the $0-20 \mathrm{~cm}$ soil layer during 2000-2004. Xi et al. (2011) estimated SOCs $(768.1 \mathrm{Tg})$ and $\operatorname{SOCd}\left(3.33 \mathrm{~kg} \mathrm{~m}^{-2}\right)$ in topsoil $(0-20 \mathrm{~cm})$ of NE plain of China based on the multi-purpose regional geochemical survey data conducted in 20042006. Overall trends show that SOCd and SOCs are higher in the northeast and lower in the southwest regions of NE China.

The objective of this study was to analyze the temporal and spatial distribution and variation of SOCd and SOCs in the arable layer of the major black soil regions in croplands of NE China from data collected in 1980, 2000 and 2011. The goal is to help to maintain and improve the quality of black soils in order to protect black soil resources.

\section{Materials and Methods}

\subsection{Study regions}

We selected three major black soil regions (Hailun, Shuangcheng and Gongzhuling Counties) which are used for maize (Zea mays) cultivation in NE China as study regions (Figure 1). Hailun County is located in the middle of Heilongjiang Province $\left(46^{\circ} 58^{\prime}\right.$ $\left.47^{\circ} 52^{\prime} \mathrm{N}, 126^{\circ} 14^{\prime}-127^{\circ} 45^{\prime} \mathrm{E}\right)$ and has a continental monsoon climate with a long, cold winter and a short, warm summer in the temperate zone. This county has a mean annual temperature of $1.5^{\circ} \mathrm{C}$, an annual precipitation of 500-600 $\mathrm{mm}$ and an annual frostless period of 130 days. Black soil is the dominant soil type in this region. Shuangcheng County is located in southern Heilongjiang Province $\left(45^{\circ} 08^{\prime}-45^{\circ} 43^{\prime} \mathrm{N}\right.$, $\left.125^{\circ} 41^{\prime}-126^{\circ} 42^{\prime} \mathrm{E}\right)$. It belongs to the same climate zone as Hailun but has a mean annual temperature of $3.6{ }^{\circ} \mathrm{C}$, an annual precipitation of $569.1 \mathrm{~mm}$, and an annual frostless period of 137 days. The major soil types are black soils, chernozem, meadow soils, 
boggy soils and sandy soils. Finally, Gongzhuling County is located in the middle of Jilin Province $\left(43^{\circ} 11^{\prime}-44^{\circ} 09^{\prime} \mathrm{N}, 124^{\circ} 10^{\prime}-126^{\circ} 18^{\prime} \mathrm{E}\right)$. This area has a sub-humid continental monsoon climate in the temperate zone, with a mean annual temperature of $5.6{ }^{\circ} \mathrm{C}$, an annual precipitation of $594.8 \mathrm{~mm}$ and an annual frostless period of 144 days. The major soil types are black soils, chernozem, meadow soils, dark brown soil and boggy soils (Gao, 2012).
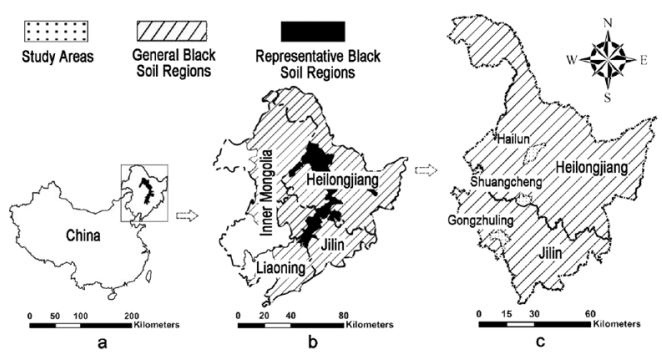

Figure 1. Location of study regions. a: location of representative black soil regions in China, b: location of representative black soil regions in NE China and c: location of study regions in representative black soil regions.

\subsection{Data sources}

In 1980, soil samples of the cropland arable layer (Figure 2-a) were collected from the sample records for the arable layer of study regions, noted in Hailun Soil (1985)*2, Shuangcheng Soil (1985)*3 and Gongzhuling Soil $(1982)^{* 4}$, which were finished during the period of the second national soil survey in China (1979-1985). With the help of GIS technology, vector sampling maps were designed with 134 samples (56 samples in Hailun, 27 samples in Shuangcheng and 51 samples in Gongzhuling) using the descriptions of the sample records.

${ }^{* 2}$ Hailun soil survey office. 1985. Hailun Soil. pp: 24-50. ${ }^{* 3}$ Shuangcheng soil survey office. 1985. Shuangcheng Soil. pp: 60-93. ${ }^{* 4}$ Gongzhuling soil survey office. 1982. Gongzhuling Soil. pp: 50-125.
In the fall of 2000, soil samples of the cropland arable layer (Figure 2-b) were collected from the study regions. Five random samples $(2.5 \mathrm{~cm}$ diameter each) were taken from each sampling plot to create a composite soil sample. The coordinates of the center sample were specified using a portable global positioning system (GPS), and the surroundings and land use conditions were noted in detail. The vector sampling maps were then designed by GIS using 245 samples (75 samples from Hailun, 100 samples from Shuangcheng and 70 samples from Gongzhuling). In the fall of 2011, soil samples (Figure 2-c) were also collected; the distance between each pair of samples was $0.5 \mathrm{~km}$, and the coordinates of each sample were recorded. The sampling and mapping methods were the same as in 2000, with 276 samples collected (93 samples in Hailun, 100 samples in Shuangcheng, and 83 samples in Gongzhuling).

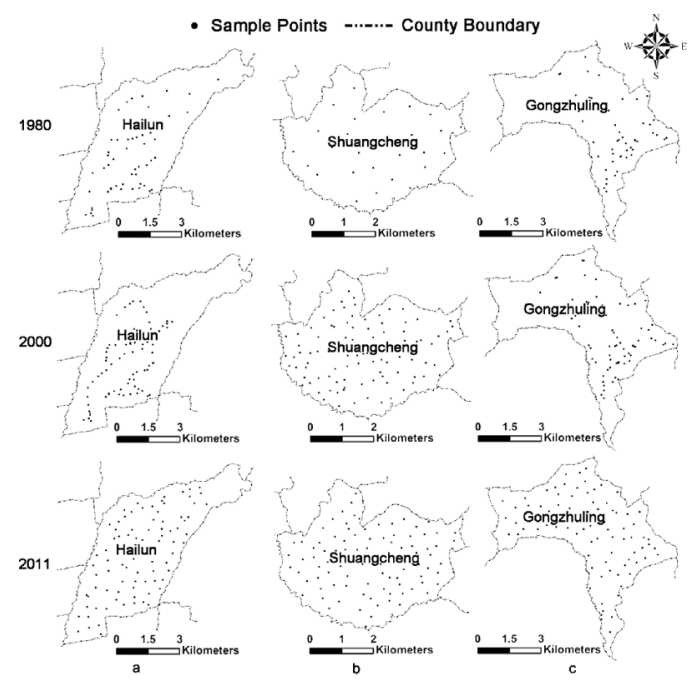

Figure 2. Sampling distribution of study regions in 1980, 2000 and 2011. Each column represents the same study region in different years; column a is Hailun County, column b is Shuangcheng County and column c is Gongzhuling County. Each row represents the same year for each of the study regions. 


\subsection{Data analysis and statistics}

In this study, SOC was determined by using an element analyzer (Elementar Vario EL III, Germany), with soil samples being air-dried, passed through a 2 $\mathrm{mm}$ sieve, and ground before analysis. Bulk density was measured by the field core method with a ring, using the ratio between the mass of oven-dry soil material and the volume of the undisturbed fresh sample. Based on geographic information system (GIS) processing, the cropland evaluation units were extracted by overlaying the vector soil map and the land use map, resulting in a total number of 1462 evaluation units in Hailun, 1263 evaluation units in Shuangcheng and 1263 evaluation units in Gongzhuling. Each evaluation unit was subsequently assigned a value by applying an interpolation method of inverse distance weighted (IDW) and zonal statistics. The classification of SOCd and its variation and SOCs and its variation employed an equalinterval method. All data were calculated using SPSS Statistics 17.0 software for Windows (SPSS, 2008).

\subsection{Estimation of SOC density and storage}

The SOCd $\left(\mathrm{kg} \mathrm{m}^{-2}\right)$ and the SOCs storage (Tg) of the arable layer $(0-20 \mathrm{~cm})$ in this study were calculated using the following equations (Post et al., 1982; Sun et al., 2010):

$$
\begin{gathered}
\mathrm{SOC}_{\mathrm{d}}=\mathrm{E} \cdot \mathrm{D} \cdot \mathrm{C} \cdot(1-\mathrm{G}) / 10^{2} \\
\mathrm{SOC}_{\mathrm{S}}=\mathrm{S} \cdot \mathrm{SOC}_{\mathrm{d}} / 10^{9}
\end{gathered}
$$

Where $\mathrm{E}(\mathrm{cm})$ is the depth of layer, $\mathrm{D}\left(\mathrm{g} \mathrm{cm}^{-3}\right)$ is the soil bulk density, $\mathrm{C}\left(\mathrm{g} \mathrm{kg}^{-1}\right)$ is the organic $\mathrm{C}$ content, $\mathrm{G}(\%)$ is the volumetric percentage of the fraction $>2$ $\mathrm{mm}$ (gravel fraction), and $\mathrm{S}\left(\mathrm{m}^{2}\right)$ is the area covered by the soil type.

\section{Results and Discussion}

\subsection{Distribution and variation of SOCd in study regions}

SOCd has become a very important factor in estimating SOCs (Xie et al., 2004; Liu et al., 2013), and Table 1 provides the results of SOCd from the arable layer of cropland soil collected in the study regions. In 1980, 2000 and 2011, the mean SOCd across these study regions were $4.88 \mathrm{~kg} \mathrm{~m}^{-2}, 4.48 \mathrm{~kg}$ $\mathrm{m}^{-2}$ and $4.24 \mathrm{~kg} \mathrm{~m}^{-2}$, respectively. A comparison of the different study regions over the same year finds the highest mean SOCd in Hailun, a medium SOCd in Shuangcheng and the lowest SOCd in Gongzhuling. Moreover, the data show an overall downward trend in SOCd (with a mean decrease of $0.64 \mathrm{~kg} \mathrm{~m}^{-2}$ ) over the past 30 years. All regions present a decrease between 1980 and 2000. While a SOCd increase is observed in Hailun $\left(0.09 \mathrm{~kg} \mathrm{~m}^{-2}\right)$ and Shuangcheng $(0.11 \mathrm{~kg}$ $\mathrm{m}^{-2}$ ) between 2000 and 2011, all study regions show an overall decrease in SOCd between 1980 and 2011, with mean SOCd decreases of $0.68 \mathrm{~kg} \mathrm{~m}^{-2}, 0.18 \mathrm{~kg}$ $\mathrm{m}^{-2}$ and $1.05 \mathrm{~kg} \mathrm{~m}^{-2}$ for Hailun, Shuangcheng and Gongzhuling, respectively.

Looking at the variation of SOCd over the different time periods, the SOCd decline in Hailun and Shuangcheng between 1980 and 2000 is greater than in other periods, with a mean decrease of $0.76 \mathrm{~kg} \mathrm{~m}^{-2}$ in Hailun, and 0.29 $\mathrm{kg} \mathrm{m}^{-2}$ in Shuangcheng. However, an increase in SOCd occurs in Hailun and Shuangcheng between 2000 and 2011. Only Gongzhuling shows a decrease in SOCd (of $0.93 \mathrm{~kg} \mathrm{~m}^{-2}$ ) between 2000 and 2011. The results of this study were consistent with the studies of Wang et al. (2002) and Xi et al. (2011), which indicated that after black soil reclamation, the SOCd of the arable layer markedly decreased but tended to balance out after 2035 years.

Based on the distribution of SOCd in the arable layers of these study regions (Figure 3), a high trend in the northeast and a low trend in the southwest is evident in Hailun across the three years studied (Figure 3-a). 
Table 1. SOCd of the arable layer in different study regions. 1980, 2000 and 2011 describe the mean SOCd in different study regions; 1980-2000, 2000-2011 and 1980-2011 describe the variation in SOCd values across the different study regions and time periods.

\begin{tabular}{ccccccc}
\hline \multirow{2}{*}{ Study Region } & \multicolumn{3}{c}{ Mean of SOCd $\left(\mathrm{kg} \mathrm{m}^{-2}\right)$} & \multicolumn{3}{c}{ Variation $\left(\mathrm{kg} \mathrm{m}^{-2}\right)$} \\
\cline { 2 - 7 } & 1980 & 2000 & 2011 & $1980-2000$ & $2000-2011$ & $1980-2011$ \\
\hline Hailun & 8.09 & 7.32 & 7.41 & -0.77 & 0.09 & -0.68 \\
Shuangcheng & 3.45 & 3.16 & 3.27 & -0.29 & 0.11 & -0.18 \\
Gongzhuling & 3.09 & 2.97 & 2.04 & -0.12 & -0.93 & -1.05 \\
\hline Mean & 4.88 & 4.48 & 4.24 & -0.39 & -0.24 & -0.64 \\
\hline
\end{tabular}

Similarly, in Shuangcheng, a trend towards high SOCd in the east and low SOCd in the west was also observed during the three years studied (Figure 3-b). Additionally, there is an observable trend toward lower SOCd in Gongzhuling (Figure 3-c). The SOCd ranges for Hailun in 1980, 2000 and 2011 are 5.22$11.83 \mathrm{~kg} \mathrm{~m}^{-2}$ (with a mean of $8.09 \mathrm{~kg} \mathrm{~m}^{-2}$ ), 4.08-11.49 $\mathrm{kg} \mathrm{m}^{-2}$ (with a mean of $7.32 \mathrm{~kg} \mathrm{~m}^{-2}$ ) and 2.81-12.29 $\mathrm{kg} \mathrm{m}^{-2}$ (with a mean of $7.41 \mathrm{~kg} \mathrm{~m}^{-2}$ ), respectively. In Shuangcheng, the SOCd ranges for 1980, 2000 and 2011 are $2.14-6.98 \mathrm{~kg} \mathrm{~m}^{-2}$ (with a mean of $3.45 \mathrm{~kg}$ $\mathrm{m}^{-2}$ ), $1.79-6.81 \mathrm{~kg} \mathrm{~m}-2$ (with a mean of $3.16 \mathrm{~kg} \mathrm{~m}^{-2}$ ) and $1.83-5.16 \mathrm{~kg} \mathrm{~m}^{-2}$ (with a mean of $3.27 \mathrm{~kg} \mathrm{~m}^{-2}$ ), respectively. The SOCd ranges in Gongzhuling for 1980, 2000 and 2011 are $1.29-4.93 \mathrm{~kg} \mathrm{~m}^{-2}$ (with a mean of $3.09 \mathrm{~kg} \mathrm{~m}^{-2}$ ), 1.21-5.20 $\mathrm{kg} \mathrm{m}^{-2}$ (with a mean of $2.97 \mathrm{~kg} \mathrm{~m}^{-2}$ ) and $0.17-4.94 \mathrm{~kg} \mathrm{~m}^{-2}$ (with a mean of $2.04 \mathrm{~kg} \mathrm{~m}^{-2}$ ), respectively.

According to data statistics, $59.96 \%$ of the total area of Hailun had a SOCd above $8.09 \mathrm{~kg} \mathrm{~m}^{-2}$ in 1980 , while the area percentage decreased to $38.23 \%$ in 2000 , and it decreased further to $31.27 \%$ in 2011 . In Shuangcheng, $61.56 \%$ of the total area had a SOCd above $3.45 \mathrm{~kg} \mathrm{~m}^{-2}$ in 1980, which decreased to $46.43 \%$ in 2000 but increased to $60.33 \%$ by 2011 . Within this area, the increase between 2000 and 2011 was small. In Gongzhuling, the area percentage also decreased gradually from $44.53 \%$ in 1980 to $35.06 \%$ in 2000 , and then to $16.11 \%$ in 2011 . Overall, the results indicate that arable land degradation in the major black soil regions of NE China increased over the past 30 years.

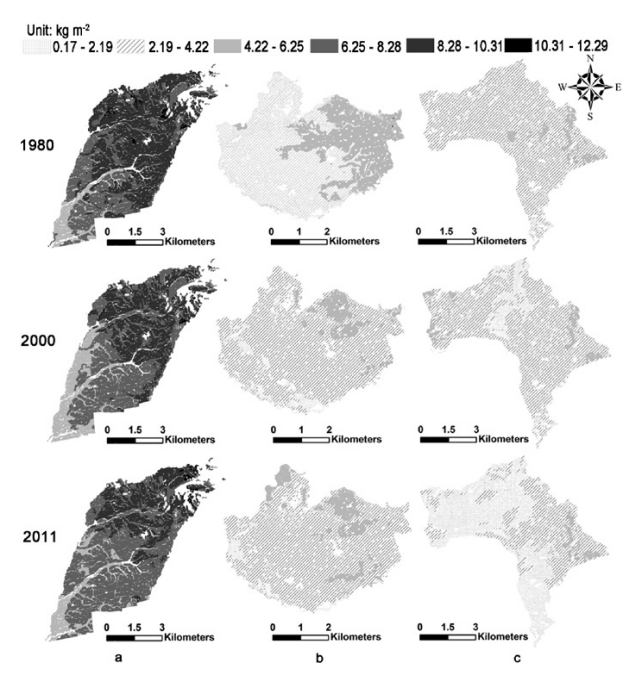

Figure 3. Distribution of SOCd in the study regions. Each column represents the same study region in different years; column a is Hailun County, column b is Shuangcheng County and column c is Gongzhuling County. Each row represents the same year across the different study regions.

The distributions of SOCd variation in the arable layers of these study regions during the different time periods are shown in Figure 4. Figure 4-a shows the variation of SOCd in Hailun and indicates a relatively uniform decrease overall between 1980 and 2000. However, there are observable differences between 2000 and 2011, with SOCd variably increasing in the northeast and southeast but SOCd decreasing within the middle region of Hailun. 
Over the past 30 years, the SOCd of most of the land area of Hailun $(90.65 \%)$ experienced a net decrease, except for northeast Hailun $(9.35 \%)$, where SOCd increased to some extent. A similar situation also occured in Shuangcheng (Figure 4-b) between 1980 and 2000. The SOCd in most of Shuangcheng decreased, except in the north (which accounts for $34.67 \%$ of the total Shuangcheng area), which exhibited an increase in SOCd. Between 2000 and 2011, however, an observable increase occured in the middle region (which includes approximately $80 \%$ of the land area) of Shuangcheng. Thus, between 1980 and 2011, the north and the middle of Shuangcheng exhibited a slight increase in SOCd, while the other areas exhibited a decrease. Gongzhuling exhibited a different pattern of SOCd variation relative to the other counties (Figure 4-c). Between 1980 and 2000, most regions lost SOC density, but the western regions and a small portion of the east exhibited an increase. Between 2000 and 2011, SOCd in the western and southern region of Gongzhuling exhibited a relatively large decrease, and only eastern Gongzhuling exhibited some SOCd increase. Generally speaking, between 1980 and 2011, there was an overall decreasing trend in Gongzhuling, with relatively serious losses in the south and a small increase in the east (which only accounts for $3.47 \%$ of the total area of Gongzhuling). Overall, the decrease in SOCd over many areas during the past 30 years, especially between 2000 and 2011, indicates a serious soil degradation phenomenon due to unreasonable land use. Thus, more reasonable fertilization or preservation practices should be applied in future in terms of reasonable fertilization including organic fertilizers or reasonable inorganic fertilizers (mainly nitrogen) could increase SOCd (Wang et al., 2012; Batlle-Bayer et al, 2010; Nayak et al., 2009).

\subsection{Distribution and variation of SOCs in study regions}

Table 2 shows SOCs in the arable layer of cropland soil for the study regions. The total amounts of SOCs for all study regions in 1980, 2000 and 2011 were $38.02 \mathrm{Tg}$, $34.56 \mathrm{Tg}$ and $33.37 \mathrm{Tg}$, respectively.
A comparison of the different study regions within the same year, found that total SOCs decreased from Hailun to Shuangcheng to Gongzhuling County. The SOCs total in Hailun was considerably higher than the other study regions due to the high SOM content, while Gongzhuling had the lowest SOCs among these study regions. Moreover, each study region had a different pattern of SOCs fluctuation over time. Overall, SOCs exhibited a net decrease in all study regions between 1980 and 2000. The greatest decrease in SOCs during this time occured in Hailun (a total decrease of 2.30 $\mathrm{Tg}$ ), while no obvious variation in Hailun was observed between 2000 and 2011. In the same 2000 to 2011 time period, an increase in SOCs was measured in Shuangcheng $(0.42 \mathrm{Tg})$, and a decrease was measured in Gongzhuling $(1.61 \mathrm{Tg})$. The total decrease in SOCs over all study regions between 1980 and 2011 was 4.65 $\mathrm{Tg}$. The total decreases observed in Hailun $(2.3 \mathrm{Tg})$ and Gongzhuling $(1.86 \mathrm{Tg})$ were greater than the decreases observed in Shuangcheng $(0.49 \mathrm{Tg})$.

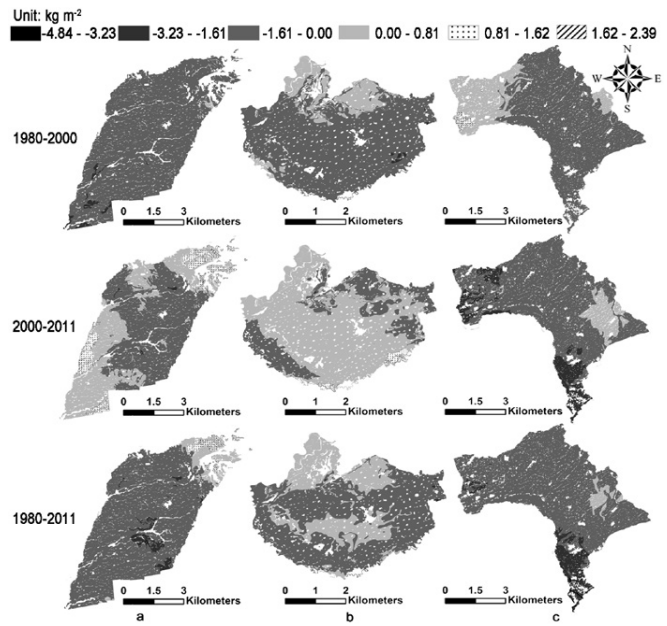

Figure 4. Variation of SOCd in the study regions. Each column represents the same study region between the different interval year; column a is Hailun County, column b is Shuangcheng County and column c is Gongzhuling County. Each row represents the same time interval for each of the study regions. 
Table 2. SOCs of the arable layer in different study regions. 1980, 2000 and 2011 describe the mean SOCs in different study regions. 1980-2000, 2000-2011 and 1980-2011 describe the change in SOCs mean for the different study regions and periods.

\begin{tabular}{ccccccc}
\hline \multirow{2}{*}{ Study Region } & \multicolumn{3}{c}{ Total of SOCs (Tg) } & \multicolumn{3}{c}{ Variation (Tg) } \\
\cline { 2 - 7 } & 1980 & 2000 & 2011 & $1980-2000$ & $2000-2011$ & $1980-2011$ \\
\hline Hailun & 22.87 & 20.57 & 20.57 & -2.30 & 0.00 & -2.30 \\
Shuangcheng & 8.42 & 7.51 & 7.93 & -0.91 & 0.42 & -0.49 \\
Gongzhuling & 6.73 & 6.48 & 4.87 & -0.25 & -1.61 & -1.86 \\
\hline Total & 38.02 & 34.56 & 33.37 & -3.46 & -1.19 & -4.65 \\
\hline
\end{tabular}

The distributions of SOCs were uneven within the arable layers of these study regions (Figure 5). For each of the three years studied, the southern and middle regions of Hailun had higher SOCs than the northern region (Figure 5-a). Similarly, in Shuangcheng, the eastern and middle regions had greater SOCs than the northern and southern regions for all years tested (Figure 5-b). However, Gongzhuling stored less SOC than the other two counties (Figure 5-c). The SOCs ranges for Hailun in 1980,2000 and 2011 were $1.67 \times 10^{-6} \mathrm{Tg} \sim 1.23 \mathrm{Tg}$ (a total of $22.87 \mathrm{Tg}$ ), $1.33 \times 10^{-6} \mathrm{Tg} \sim 1.05 \mathrm{Tg}$ (a total of $20.57 \mathrm{Tg}$ ) and $1.52 \times 10^{-6} \mathrm{Tg} \sim 1.08 \mathrm{Tg}$ (a total of 20.57 $\mathrm{Tg}$ ), respectively. The SOCs ranges for Shuangcheng in 1980,2000 and 2011 were $2.13 \times 10^{-8} \mathrm{Tg} \sim 1.04 \mathrm{Tg}$ (a total of $8.42 \mathrm{Tg}$ ), $1.73 \times 10^{-8} \mathrm{Tg} \sim 0.94 \mathrm{Tg}$ (a total of $7.51 \mathrm{Tg}$ ) and $1.95 \times 10^{-8} \mathrm{Tg} \sim 0.94 \mathrm{Tg}$ (a total of 7.93 $\mathrm{Tg}$ ), respectively. Additionally, the SOCs ranges for Gongzhuling in 1980,2000 and 2011 were $5.08 \times 10^{-7}$ $\mathrm{Tg} \sim 0.29 \mathrm{Tg}$ (a total of $6.73 \mathrm{Tg}$ ), $4.62 \times 10^{-7} \mathrm{Tg} \sim 0.31 \mathrm{Tg}$ (a total of $6.48 \mathrm{Tg}$ ) and $1.26 \times 10^{-7} \mathrm{Tg} \sim 0.18 \mathrm{Tg}$ (a total of $4.87 \mathrm{Tg}$ ), respectively.

Figure 6 shows the distribution of SOCs variation for the arable layer in these study regions during the different time intervals. Figure 6-a shows the SOCs variation for Hailun, and indicates an overall uniform decrease between 1980 and 2000. However, between 2000 and 2011, SOCs in the northern, western and southern regions exhibited variable increases, while SOCs in the middle region of Hailun decreased. In general, over the past 30 years, the SOCs of Hailun exhibited an overall decrease across $91.10 \%$ of the total area, excluding the northeast of Hailun, where SOCs increased to some extent.

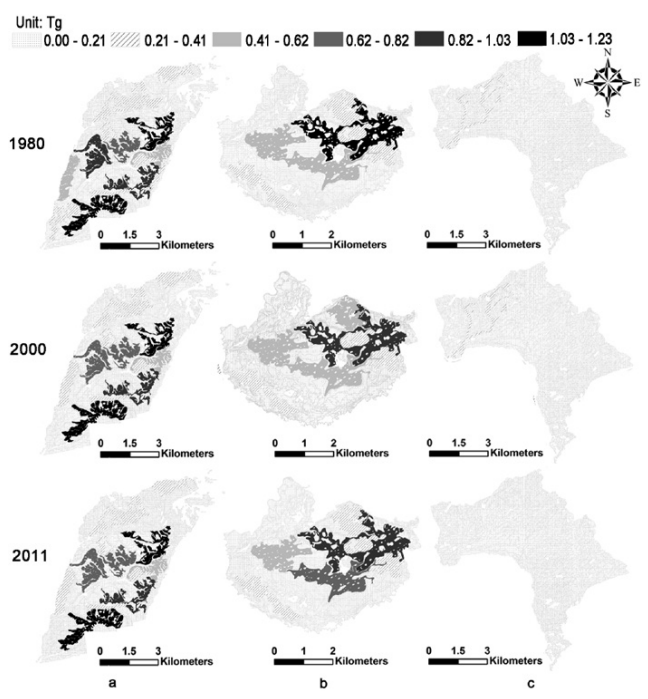

Figure 5. Distribution of SOCs in the study regions. Each column represents the same study region in different years; column a is Hailun County, column b is Shuangcheng County and column c is Gongzhuling County. Each row represents the same year for each of the study regions.

Between 1980 and 2000 in Shuangcheng (Figure 6-b), the SOCs variation decreased over $83.31 \%$ of the total area, except in the north where an observable increase, mainly occurred in the middle of Shuangcheng. This area accounts for approximately $75 \%$ of the total area between 2000 and 2011. Thus, over the last 30 years, SOCs increased slightly, except in the north and middle of Shuangcheng, but it has decreased in other regions (accounting for $66.95 \%$ of the total area). 
SOCs followed a different pattern in Gongzhuling over the last 30 years relative to the other two counties (Figure 6-c). Between 1980 and 2000, there was an increase in SOCs within the west and a small part of the east, but between 2000 and 2011, most parts of Gongzhuling exhibited a decrease, with only a small part of eastern Gongzhuling showing any increase in SOCs. Thus, there was an overall downward trend in the SOCs of Gongzhuling between 1980 and 2011, where $96.53 \%$ of the county exhibited a decrease, and only $3.47 \%$ of the total area in Gongzhuling exhibited an increase. Overall, the storage data show that it has exerted a serious soil degradation in the arable land over the past 30 years. Thus, we need also to conduct the reasonable agriculture practices mainly including field fertilization (organic and combined application of mineral and organic fertilizers) and rotation management practice which will increase SOCs as well as SOCd, improving C sequestion (Wang et al., 2013; Zhang et al., 2010; Pathak et al., 2011)

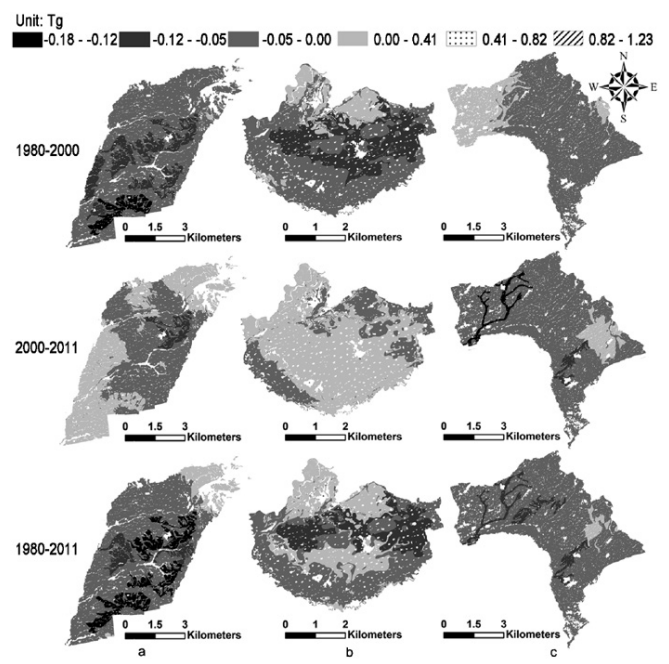

Figure 6. Variation of SOCs in the study regions. Each column represents the same study region between the different interval year; column a is Hailun County, column b is Shuangcheng County and column c is Gongzhuling County. Each row represents the same time interval for each of the study regions.

\subsection{Changes in SOCd and SOCs in different soil types}

Different cropland soil types provide different levels of original SOM/SOC. An estimation of SOCd and SOCs across different soil types could indicate the capacity for SOC retention in those various soil types. In this study, we estimated and described changes in SOCd and SOCs for different soil types in 1980, 2000 and 2011 using the statistic function in GIS software (Figure 7).

Black soils, which are the dominant soil type in these study regions, accounted for $57.92 \%$ of the cropland soil area. The mean SOCd for almost all soil types exhibited an overall decrease between 1980 and 2011, but a rapid decrease was not observed in black soils between 2000 and 2011. The largest decrease $\left(1.95 \mathrm{~kg} \mathrm{~m}^{-2}\right)$ occured in brown soils, followed by alluvial soils (with a mean decrease of $1.54 \mathrm{~kg} \mathrm{~m}^{-2}$ ). The reduction in SOCd for the other soil types was as follows: aeolian sandy soils $>$ thin-layer black soils $>$ paddy $\quad$ soils $>$ black soils $>$ planosols $>$ meadow soils $>$ ash-sandy soils $>$ chernozems $>$ peat soils. These decreases may have been caused by human activities, such as widespread land reclamation and unreasonable cultivation of cropland soils during the past 30 years. A small increase in SOCd only occured in forest soils, boggy soils and flooded soils.

Figure 7 also shows that almost all soil types experienced a SOCs decreases to varying degrees during the past 30 years. The most serious decrease was observed in black soils, with a total decrease of $2.91 \mathrm{Tg}$. Another serious decrease was observed in meadow soils, with a total decrease of $0.67 \mathrm{Tg}$. Decreasing amounts of SOCs loss were also observed in the other soil types as follows: flooded soils $>$ chernozems $>$ aeolian sandy soils $>$ brown soils $>$ thin-layer black soils $>$ paddy soils $>$ planosols $>$ ash-sandy soils $>$ forest soils. The SOCs of peat soils was the smallest (of $0.002 \mathrm{Tg}$ ) approximately equally among 1980, 2000 and 2011 The SOCs of boggy and flooded soils in $2011 \mathrm{did}$ increase slightly since 1980 . 


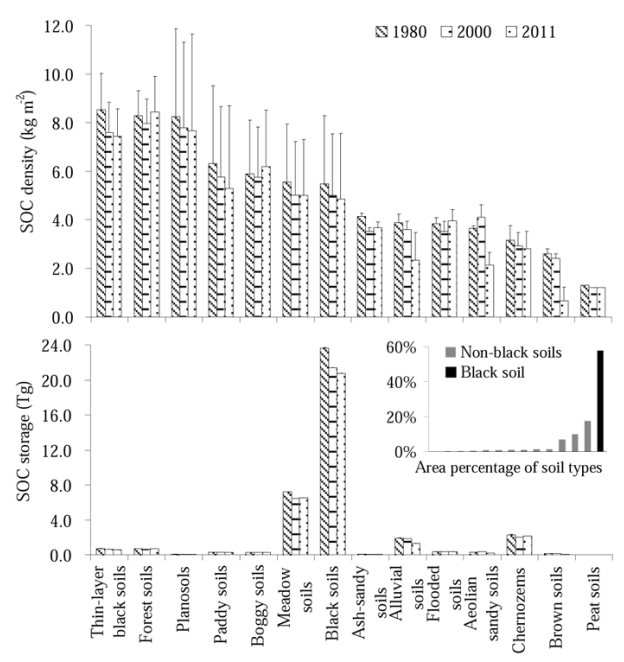

Figure 7. SOCd and SOCs for the arable layer in different soil types and time periods.

\section{Conclusion}

This study used data from three study regions across the major black soil regions of NE China to estimate the SOCd and SOCs trends over the past 30 years. An mean decrease in SOCd of $0.64 \mathrm{~kg} \mathrm{~m}^{-2}$ and an total decrease in SOCs of $4.65 \mathrm{Tg}$ was observed in the arable layer of black soils across all study regions. In addition, the most serious decrease of SOCs was from black soils (which account for $57.92 \%$ of the cropland soil area in all study regions) with a total loss of $2.91 \mathrm{Tg}$. These results exhibited that the major black soil regions in NE China were presenting a C resource trend over the past 30 years, and in which black soil was the most important $\mathrm{C}$ resource, which would cause black soils degradation unceasingly if ignoring continuous reasonable utilization and management on black soils resoures in this region.

\section{Acknowledgements}

This research was funded by Natural Science Foundation of China (NSFC), project No. 41171237. We would like to thank the Hailun, Harbin and Gongzhuling national long-term fertility and fertilizer monitoring network for their help.

\section{References}

Batlle-Bayer, L., Batjes, N.H., Bindraban, P.S. 2010. Changes in organic carbon stocks upon land use conversion in the Brazilian Cerrado: a review. Agric. Ecosyst. Environ. 137(1-2), 47-58.

Bernoux, M, Carvalho, M.D.C.S., Volkoff, B.,Cerri ,C.C. 2002. Brazil's soil carbon stocks. Soil Sci. Soc. Am. J. 66, 888-896.

Bohn, H.L. 1982. Estimate of organic carbon in the world soils. Soil Sci. Soc. Am. J. 46, 1118-1119.

Edmondson, J.L., Davies, Z.G., McHugh, N., Gaston, K.J., Leake, J.R. 2012. Organic carbon hidden in urban ecosystems. Sci. Rep. 2: 963, DOI: 10.1038/ srep00963.

Fan, H.M., Cai, Q.G., Chen, G., Cui, M. 2005. Comparative study of the soil erosion and control in the three major black soils regions in the world. J. Nat. Resour. 20 (3), 387-393.

Franzluebbers, A.J. 2010. Achieving soil organic carbon sequestration with conservation agricultural systems in the southeastern united states. Soil Sci. Soc. Am. J. 74, 347-357.

Gao, G.W. 2012. Changes of organic carbon density, storage and $\mathrm{C}$-fixed potential in croplands in northeastern black soil regions. Master thesis, Shenyang Agricultural University. China. 
Han, F.P., Hu, W., Zheng, J.Y., Du, F., Zhang, X.C. 2010. Estimating soil organic carbon storage and distribution in a catchment of Loess plateau, China. Geoderma. 154, 261-266.

Huang, Y., Sun, W.J. 2006. Changes of organic carbon in farmland topsoil during the past 20 years in Chinese Mainland. Bull. Sci. Technol. 51 (7), 750-763.

Kumar, S., Leal, R., Liu, D., Rafiq, R. Estimating the spatial distribution of organic carbon density for the soils of Ohio, USA. J. Geogr. Sci. 2013, 23(2), 280-296

Lal, R. 2004. Soil carbon sequestration impacts on global climate change and food security. Science, 304, 1623-1627.

Liu, F. 2011. Profile distribution of organic carbon of four typical soils in China. Earth Sci. Front. 18 (6), 020-026.

Liu, H.Y. 2011. Dynamics change and quantification of sequestration potential for soil organic carbon in croplands in Liaoning Province. Doctoral thesis, Shenyang Agricultural University. China.

Liu, Y., Wang, C., Yue, W.Z., Hu, Y.Y. 2013. Storage and density of soil organic carbon in urban topsoil of hilly cities: a case study of chongqing municipality of china. Chin. Geogra. Sci. 23(1), 26-34.

Nayak, P., Patel, D., Ramakrishnan, B., Mishra, A.K., Samantaray, R.N. 2009. Long-term application effects of chemical fertilizer and compost on soil carbon under intensive rice-rice cultivation. Nutr. Cycl. Agroecosys. 83(3), 259-269.

Pan, G.X. 1999. Study on soil organic and inorganic carbon of China. Bull. Sci. Technol. 5, 330-332.

Pathak, H., Byjesh, K., Chakrabarti, B., Aggarwal ,P.K. 2011. Potential and cost of carbon sequestration in Indian agriculture: estimates from long-term field experiments. Field Crop. Res.120, 102-111.
Piao, S.L., Fang, J.Y., Ciais, P., Peylin, P., Huang, Y., Sitch, S., Wang, T. 2009. The carbon balance of terrestrial ecosystems in China. Nature, 458, 1009-1013.

Post, W.M., Emanuel, W.R., Zinke, P.J., Stangenberger ,A.G. 1982. Soil carbon pools and world life zones. Nature, 298(8), 156-159.

Qin, Z.C., Huang, Y., Zhuang, Q.L. 2013. Soil organic carbon sequestration potential of cropland in China, Global Biogeochem. Cycles. 27, 711-722.

SPSS. 2008. SPSS Version 17.0 for Windows SPSS Inc., Chicago, USA.

Sun, W.X., Shi, X.Z., Yu, D.S., Wang, K., Wang, H.J. 2004. Estimation of soil organic carbon storage based on 1:1 M soil database of China. Sci. Geogr. Sin. 24(5), 568-572.

Sun, W.J., Huang, Y., Zhang, W., Yu, Y.Q. 2010. Carbon sequestration and its potential in agricultural soils of China. Global Biogeochem. Cycles, 24, GB3001, doi: 10.1029/ 2009GB003484.

Thorburn, P.J., Meier, E.A., Collins, K., Robertson, F.A. 2012. Changes in soil carbon sequestration, fractionation and soil fertility in response to sugarcane residue retention are site-specific. Soil \& Till. Res. 120, 99-111.

Wang, J., Lu, C., Xu, M., Zhu ,P., Huang, S., Zhang, W., Peng, C., Chen, X., Wu, L. 2013. Soil organic carbon sequestration under different fertilizer regimes in north and northeast China: RothC simulation. Soil Use Manage. 29, 182-190.

Wang, J.K., Li, S.Y., Zhang, X.D., Wei, D., Chi, F.Q. 2007. Spatial and temporal variability of soil quality in typical black soil area in Northeast China in 20 years. Chin. J. Eco-Agric. 2, 26-31.

Wang, S.X., Liang, X.Q., Luo, Q.X., Fan, F., Chen, Y.X., Li, Z.Z., Sun, H.X., Dai, T.F., Wan, J.N., 
Li, X.J. 2012. Fertilization increases paddy soil organic carbon density. J. Zhejiang Univ-Sci. B. 13(4), 274-282.

Wu, Y.J., Wang, J.K., Li, S.Y., Wei, D., Chi, F.Q. 2007. Preliminary studies on fertility revolution of black soil: V. Organic carbon density and storage in topsoil of northeast main black soil area and spatial analysis. J. Shenyang Agric. Univ. 38 (4), 535-539.

Xi, X.H., Yang, Z.F., Cui, Y.J., Sun, S.M., Yu, C.G., Li ,M. 2011. A study of soil organic carbon distribution and storage in the Northeast Plain of China. Geosci. Front. 2(2), 115-123
Xie, X.L., Sun, B., Zhou, H.Z., Li, Z.P., Li, A.B. 2004. Organic carbon density and storage in soils of China and spatial analysis. Acta Pedol. Sin. 41 (1), 35-43.

Yan, Y.Y., Guo, Z.T., Wu, H.B., Kahmann, A.J., Oldfield, F. 2009. Spatial changes in soil organic carbon density and storage of cultivated soils in China from 1980 to 2000. Global Biogeochem. Cycles, 23, GB2021, doi: 10.1029/2008GB003428.

Zhang, W., Wang, X., Xu, M., Huang, S., Liu, H., Peng, C. 2010. Soil organic carbon dynamics under longterm fertilizations in arable land of northern China. Biogeosciences, 7, 409-425. 